\title{
Biochemical Changes Induced by Cartap Hydrochloride (50\% SP), Carbamate Insecticide in Freshwater Fish Cirrhinus mrigala (Hamilton, 1822)
}

\author{
G. Vani*†, K. Veeraiah**, M. Vijaya Kumar*, Sk. Parveen* and G.D.V. Prasad Rao*** \\ *Department of Zoology, SRR \& CVR Government Degree College (A), Vijayawada, Andhra Pradesh, India \\ **Department of Zoology and Aquaculture, Acharya Nagarjuna University, Nagarjunanagar-522 510, Guntur, \\ Andhra Pradesh, India \\ ****Department of Zoology SGS College, Jaggaiahpet, Andhra Pradesh, India \\ †Corresponding author: G. Vani; gandhamvanipradeep@gmail.com
}

Nat. Env. \& Poll. Tech. Website: www.neptjournal.com

Received: 08-11-2019

Revised: 25-11-2019

Accepted: 03-01-2020

Key Words:

Cartap hydrochloride

Cirrhinus mrigala

$\mathrm{LC}_{50}$

Glycogen

Total proteins

Nucleic acids

\begin{abstract}
The freshwater fish Cirrhinus mrigala was exposed to Cartap hydrochloride ( $50 \%$ SP) for $24,48,72$ and $96 \mathrm{~h}$. The $\mathrm{LC}_{50}$ values were found to be $0.436,0.419,0.394$ and $0.376 \mathrm{mg}^{-1}$ in static method and $0.399,0.371,0.361$ and $0.339 \mathrm{mg}^{-1}$ in continuous flow-through system. The static $\mathrm{LC}_{50}$ values are higher than the continuous flow-through method. The $\mathrm{LC}_{50}$ values showed a decreasing trend with an increase in time of exposure in both the methods. The decrease was more in a continuous flow-through method than in the static method. The fish were exposed to sub-lethal $\left(1 / 10^{\text {th }}\right.$ of $96 \mathrm{~h} \mathrm{LC}_{50}$ value 0.0376 mg. $\left.\mathrm{L}^{-1}\right)$ and lethal ( $96 \mathrm{~h} \mathrm{LC}_{50}$ value $0.376 \mathrm{mg} \cdot \mathrm{L}^{-1}$ ) concentrations of the pesticide for 24 and 96 hours to study the alterations in glycogen, total proteins and nucleic acids (DNA \& RNA) contents of various tissues viz., gill, brain, liver, kidney and muscle. Glycogen, total proteins and nucleic acids (DNA \& RNA) content values decreased in all the tissues of exposed fish and the per cent decrease is more apparent in lethal concentrations than in sub-lethal concentrations. From the present study, it can be concluded that Cartap hydrochloride caused a decline in the glycogen, total protein and nucleic acids (DNA, RNA) content in Cirrhinus mrigala and the changes are more pronounced in lethal exposure than

in sub-lethal exposure.
\end{abstract}

\section{INTRODUCTION}

Indiscriminate use of pesticides is one of the main reasons for the pollution of aquatic ecosystems. These toxic pesticides are causing deleterious effects on aquatic organisms. They are causing stress to aquatic organisms which are reflected as biochemical changes in their body (Mayers 1977). Fish acts as a bioindicator species and can be used for monitoring of water pollution as they accumulate the contaminants from polluted water and diet (Chaudary \& Jabeen 2011, Kafilzadeh et al. 2012). Fish accumulate these pollutants directly or indirectly from polluted waters and food chain (Jabeen et al. 2016, Chaudary \& Jabeen 2011). Carbamates are extensively used water-soluble pesticides in agricultural practices. In India, Cartap hydrochloride is a Carbamate pesticide which is considered as nereistoxin analog is extensively used in rice and sugarcane crops to control pests. The present investigation is aimed to study the toxic effects of Cartap hydrochloride in sub-lethal and lethal concentrations at 24 and 96 hours of exposure period on glycogen, total protein, DNA and RNA contents of freshwater fish Cirrhinus mrigala (Hamilton 1822).

\section{MATERIALS AND METHODS}

The fingerlings of the test fish Cirrhinus mrigala size 6-8 \pm $1 / 2 \mathrm{~cm}$ and weight 6-7 $\pm 1 / 2 \mathrm{~g}$ were procured from local fish hatcheries of Nandivelugu, Tenali Mandal, Guntur district, Andhra Pradesh. The fish were acclimated at $\left.\left(28 \pm 2^{\circ} \mathrm{C}\right)\right)$ in the laboratory conditions for two weeks. All the precautions laid down by APHA et al. (1998) were followed. During the acclimation period, the fish were fed with rice bran and groundnut cake. One day before the experimentation feeding was stopped. Cartap hydrochloride (50\% SP) commercial grade was purchased from Mangalagiri, Guntur District. The stock solution was prepared with water as a solvent. The acclimatized fish were exposed to static sub-lethal (0.376 mg. $\left.\mathrm{L}^{-1}\right)$ and lethal concentrations (3.76 mg.L $\left.{ }^{-1}\right)$ of Cartap hydrochloride (50\% SP) for 24 and $96 \mathrm{~h}$. The hydrographical properties of water were estimated by the modified method followed by Golterman \& Claimo (1969) method. Finney's probit analysis (Finney 1971) as reported by Roberts \% Boyce (1972) was followed to calculate the $\mathrm{LC}_{50}$ value. The $95 \%$ confidence limits of the $\mathrm{LC}_{50}$ values for each test were also calculated for different time periods 
by using SPSS software. At the end of the exposure periods, the tissues like gill, brain, liver, kidney and muscle were taken out from exposed and control fish and processed for the estimation of glycogen, total proteins and nucleic acids (DNA \& RNA). Glycogen was estimated by the method of Kemp et al. (1954), total protein by Lowry et al. (1951) and DNA and RNA by the methods of Searchy \& Maclinnis (1970a \& 1970b).

The data obtained in the present work were expressed as means of four observations \pm SD (standard deviation) and were statistically analysed using student " $t$ " test (Pillai $\&$ Sinha 1968) to compare means of treated data against their controls and the result was considered significant at $(\mathrm{P}<0.05)$ level.

\section{RESULTS AND DISCUSSION}

Glycogen, total proteins and nucleic acids (DNA \& RNA) decreased in various tissues, viz. gill, brain, liver, kidney and muscle of Cirrhinus mrigala exposed to sub-lethal and lethal concentrations of cartap hydrochloride for 24 and 96 hours were graphically represented in Fig. 1 to Fig. 8. In exposed fish per cent decrease is more apparent in lethal concentrations than at sub-lethal concentrations.

\section{Glycogen}

The changes in glycogen content observed in the various tissues of Cirrhinus mrigala after the Cartap hydrochloride exposure along with the control are graphically represented in Fig .1 and Fig. 2.

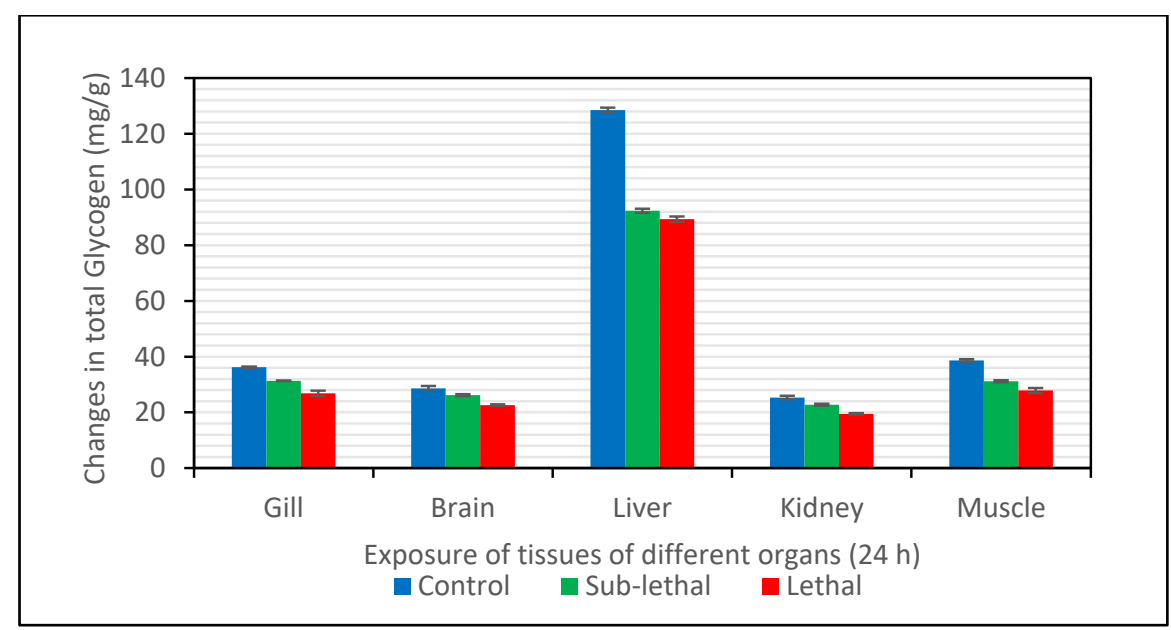

Fig.1: Changes in the glycogen content (mg/g wet weight of the tissue) in the tissue of fish Cirrhinus mrigala on exposure to sub-lethal and lethal concentration of Cartap hydrochloride (50\%SP) for 24 hours.

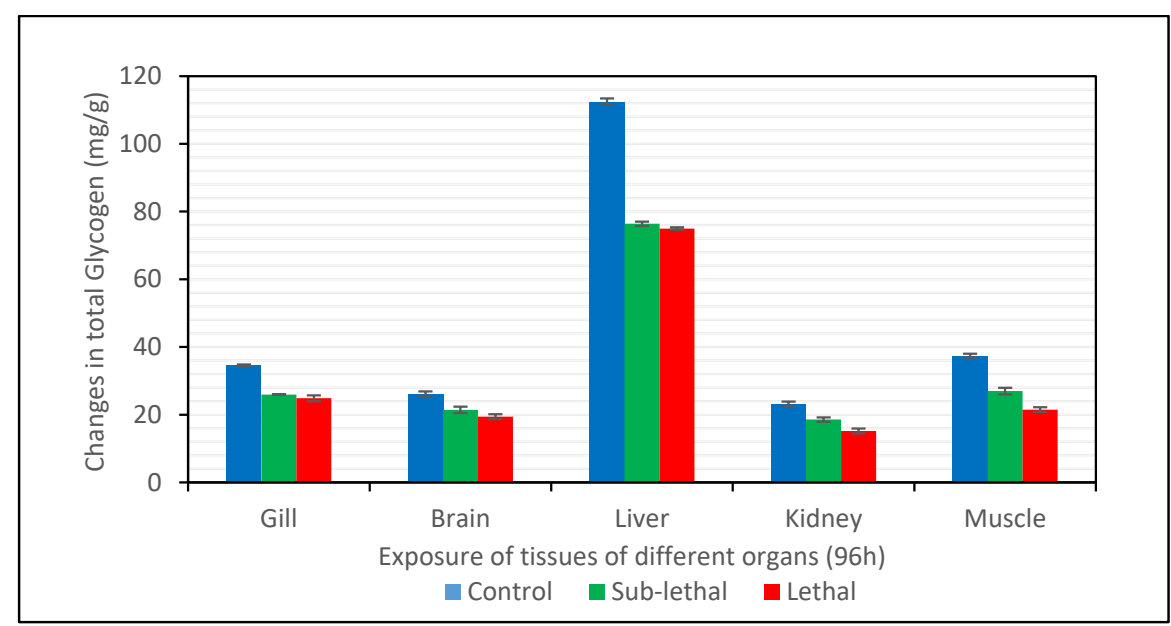

Fig. 2: Changes in the glycogen content (mg/g wet weight of the tissue) in the tissue of fish Cirrhinus mrigala on exposure to sub-lethal and lethal concentration of Cartap hydrochloride (50\% SP) for 96 hours. 
In the tissues of control fish, Cirrhinus mrigala glycogen content was in the order of:

$$
\text { Liver }>\text { Muscle }>\text { Gill }>\text { Brain }>\text { Kidney }
$$

Under exposure to sub-lethal and lethal concentrations of Cartap hydrochloride for 24 and 96 hours, the amount of glycogen was found to decrease in all the tissue of Cirrhinus mrigala. The lyotropic gradation series in terms of per cent decrement at $24 \mathrm{~h}$ and $96 \mathrm{~h}$ exposure was:

Sub-lethal -24 h: Liver $>$ Muscle $>$ Gill $>$ Kidney $>$ Brain

Lethal -24 h: Liver $>$ Muscle $>$ Gill $>$ Kidney $>$ Brain

Sub-lethal 96 h: Liver $>$ Muscle $>$ Gill $>$ Kidney $>$ Brain

Lethal-96 h: Muscle $>$ Kidney $>$ Liver $>$ Gill $>$ Brain

Exposure of Cirrhinus mrigala to Cartap hydrochloride for 24 hours caused a maximum decrease of glycogen in the liver (sub-lethal 28.117, lethal 30.453). For $96 \mathrm{~h}$ maximum decrease was found in the liver (sub-lethal 32.073) and muscle (lethal 42.570). In the present study under Cartap hydrochloride $24 \mathrm{~h}$ sub-lethal and lethal exposure minimum percentage of depletion was in the brain (8.595) and (20.96). For $96 \mathrm{~h}$ exposure minimum depletion was found in the brain (sub-lethal 18.056, lethal 25.707).

Srivastava \& Singh (2013) observed reduction in glycogen content in different tissues of freshwater fish Clarius batrachus exposed to $80 \%$ of $\mathrm{LC}_{50}\left(22.87 \mathrm{mg} . \mathrm{L}^{-1}\right)$ of Mancozeb at different time intervals of 24 and $96 \mathrm{~h}$. Sastry et al. (1982) reported decreased glycogen content of liver and muscles decreased when Channa punctatus was exposed to sub-lethal concentration of the carbamate pesticide, Sevin (1.05 mg. $\mathrm{L}^{-1}$ ) for 15, 30 and 60 days. Veeraiah et al. (2013a) observed that exposure to sub-lethal and lethal concentrations of cadmium chloride in the fish Cirrhinus mrigala for $96 \mathrm{~h}$ caused changes in the total glycogen level which may be attributed to toxic stress, resulting in the disruption of enzymes associated with carbohydrate metabolism. Bantu \& Rathnamma (2013) reported that there is a decrease in the amount of glycogen in the fish Labeo rohita exposed to sub-lethal and lethal concentrations of Dimethoate for 8 days. Priya et al. (2013) observed depletion of glycogen in the liver of freshwater teleost Channa punctatus (Bloch) when exposed to various concentrations of Imidacloprid (0.002 ppm, 0.00 ppm, 0.006 ppm, 0.008 ppm and $0.01 \mathrm{ppm}$ ) for $96 \mathrm{~h}$ suggesting the possibility of an alter from aerobic to anaerobic mode of energy metabolism of the liver. Dhanalakshmi (2013) noticed decrement in the tissue glycogen concentration in fish Cirrhinus mrigala when exposed to $0.25 \mathrm{ppm}$ concentration of the metal chromium sulphate for 24, 48, $72 \mathrm{~h}$ and 10, 20 and 30 days which may be due to its enhanced utilization, since glycogen forms the immediate source of energy to meet energy demands under metallic stress caused by test toxicant.
Tataji \& Kumar (2016) reported a decline in glycogen content of freshwater fish Channa punctatus exposed for 8 days to 1/5th of $\mathrm{LC}_{50} 96$ hours of both Butachlor technical grade and Machete (50\% EC), i.e. $32 \mathrm{ppb}$ and $71.2 \mathrm{ppb}$ for both technical and 50\% EC respectively. Reduction in glycogen content was also noticed by Naik et al. (2016) in all the tissues of Labeo rohita when exposed to sub-lethal concentrations of cypermethrin for 1, 2 and 3 weeks. Exposure of sub-lethal doses (40\% and $80 \%$ of $\mathrm{LC}_{50}$ of $24 \mathrm{~h}$ ) of glyphosate for 24 or $96 \mathrm{~h}$ against the freshwater non-target fish Channa punctatus caused significant $(\mathrm{P}<0.05)$ alteration in biochemical parameters in liver and muscle tissues of the fish Channa punctatus (Bloch) was reported by Singh et al. (2017). Veeraiah et al. (2018) observed that exposure to lethal and sub-lethal concentrations of cyhalothrin $2.5 \% \mathrm{EC}$, in the fish Ctenopharyngdon idellus for 24 and 96 hours caused a decrease in glycogen content in all tissues.

According to Dezwaan \& Zandee (1973) depletion of glycogen in tissues may be due to direct utilization of the compound for energy generation, a demand caused by pesticide-induced hypoxia. Under hypoxia condition, the fish derives its energy from anaerobic breakdown of glucose which is available to the cell by increased glycogenolysis (Chandravathy \& Reddy 1996, Rajamannar \& Manohar 1998, Rajamanickam 1992). Reduction in glycogen is probably due to its more rapid break down for energy requirement of fish (Muley et al.1996).

Liver suggested as an organ for detoxification. During exposure to Cartap hydrochloride exposure fishes came under stress condition and need more energy to cope with the toxicants. glycogen serves as reserve material. It is utilized when the body came under stress condition. Depletion of glycogen in liver and tissues may be due to increment in the glycolysis pathway. During stress conditions, the glycogen reserves depleted to meet energy demand (Rawat et al. 2002). Fall in glycogen levels indicates its rapid utilization to meet the enhanced energy demands intoxicant treated animals through glycolysis or hexose monophosphate pathway as observed by Cappon \& Nicholas (1975). The above findings support the alterations of glycogen in the present study.

\section{Proteins}

The changes in protein content observed in the various tissues of Cirrhinus mrigala after Cartap hydrochloride exposure along with the control was graphically represented in Fig. 3 and Fig. 4.

The Protein content in different tissues in control fish Cirrhinus mrigala was in the order of:

Muscle $>$ Liver $>$ Brain $>$ Kidney $>$ Gill 


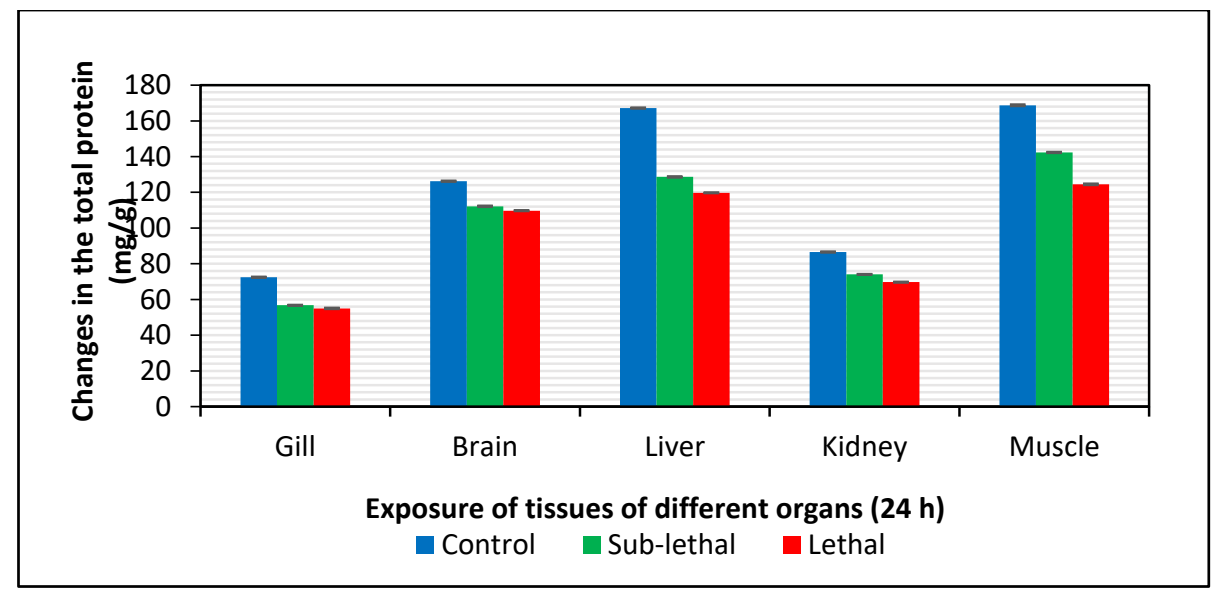

Fig. 3: Changes in protein content (mg/g wet wt of the tissue) in different tissues of fish Cirrhinus mrigala (Hamilton) on exposure to sub-lethal and lethal concentration of Cartap hydrochloride (50\% SP) for 24 hours.

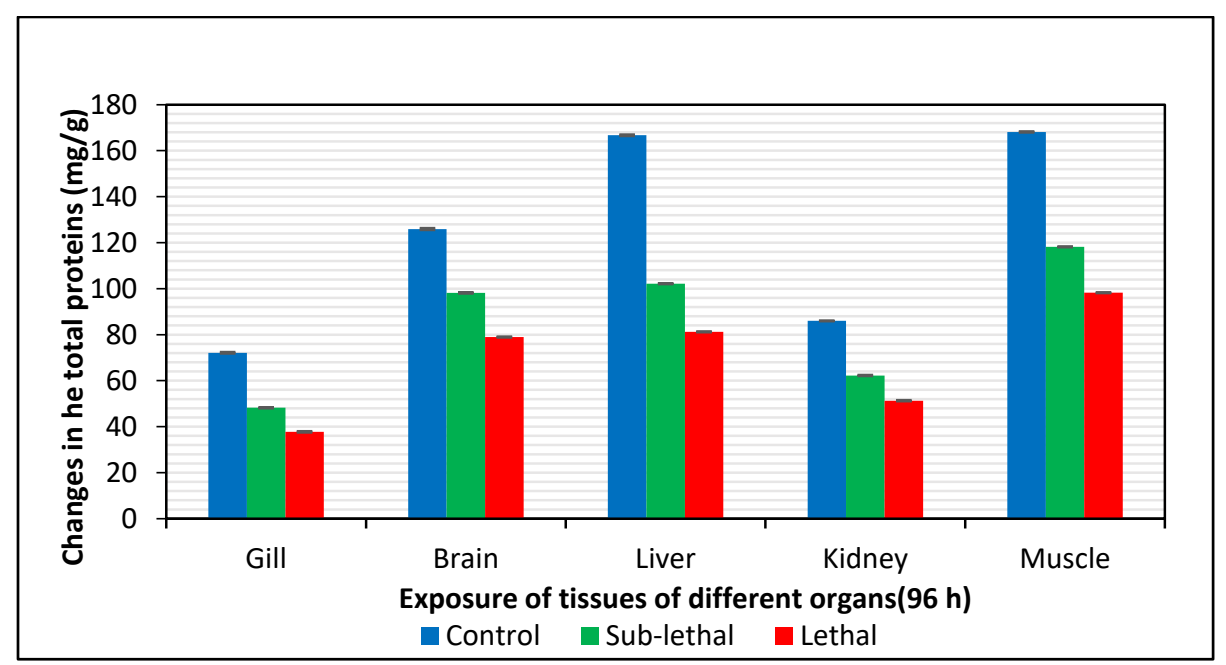

Fig. 4: Changes in protein content (mg/g wet wt of the tissue) in different tissues of fish Cirrhinus mrigala (Hamilton) on exposure to sub-lethal and lethal concentration of Cartap hydrochloride ( $50 \% \mathrm{SP}$ ) for 96 hours.

Under exposure of sub-lethal and lethal concentrations of Cartap hydrochloride for $24 \mathrm{~h}$, the amount of protein was found to decrease in all the tissue of Cirrhinus mrigala.

The lyotropic gradation series in terms of per cent decrement at $24 \mathrm{~h}$ and $96 \mathrm{~h}$ exposure was:

Sub-lethal -24 h: Liver $>$ Gill $>$ Muscle $>$ Kidney $>$ Brain Lethal-24 h- Liver $>$ Muscle $>$ Gill $>$ Kidney $>$ Brain Sub-lethal -96 h: Liver $>$ Gill $>$ Muscle $>$ Kidney $>$ Brain Lethal-96 h: Liver $>$ Gill $>$ Muscle $>$ Kidney $>$ Brain

For $24 \mathrm{~h}$ exposure maximum per cent of the decrease in total protein was observed in the liver (sub-lethal 23.05, lethal 28.33). For $24 \mathrm{~h}$ exposure minimum percentage of depletion of total protein was found in the brain (sub-lethal 11.18, lethal
13.13). For $96 \mathrm{~h}$ the percentage of decrease was maximum in the liver (sub-lethal 38.72, lethal 51.27). Similarly, for 96 $\mathrm{h}$ minimum percentage of decrease was noticed in the brain (sub-lethal 22.06, lethal 37.30).

Protein is the most primary biochemical ingredient present in large quantities in the body of fish. Liver is rich in protein and centre for various metabolism of the fish. In the present study maximum decrease of total protein in the liver is due to the increased rate of proteolytic activity or repeated break down of protein to yield energy due to stress caused due to pesticide exposure. Anitha \& Rathnamma (2016) noticed decreased protein levels in all the tissues like liver, kidney, brain, gill and muscle of Labeo rohita exposed to lethal and sub-lethal concentrations of Pyraclostrobin 20\% 
WG (carbamate) for $24 \mathrm{~h}$ and sub-lethal concentrations for 5 and 10 days. A decline in the protein content was noticed by Kumari et al. (2014) in the liver of Clarias batrachus when exposed to sub-lethal concentrations ( 2 and $4 \mathrm{mg} . \mathrm{L}^{-1}$ ) of the Carbaryl for $96 \mathrm{~h}$. A decrease in protein may be due to the impairment of protein synthesis or an increase in the rate of its degradation to amino acids. Exposure to Carbryl for 4 and 24 days, decreased protein content in liver and muscle of fish Mugil cephalus, when exposed to the lethal and sub-lethal concentration of Carbaryl for 4 days and 21 days respectively was reported by Shivanagouda et al. (2013). Kumar et al. (2017) reported a reduction in proteins in the liver and kidney of freshwater fish, Channa punctatus exposed to different sub-lethal concentrations of pesticide Carbaryl for a period of $15,30,45,60,75$ and up to 90 days. Muddassir (2015) observed significant decrease value in Total protein in the liver of Channa punctatus was treated with $0.1 \mathrm{~mL}$ Carbofuran and $0.09 \mathrm{~mL}$ Malathion pesticides at different time intervals 7, 14, 21 and 28 days. The decrement of total protein may be due to the inhibition of RNA synthesis disturbing the protein metabolism or this may be due to liver damage where most protein synthesis usually occurs, these results agreed with that of Singh \& Sharma (1998). The depletion of protein might also be attributed to spontaneous utilization of amino acids in various catabolic reactions inside the organism to combat the stress condition (Borah \& Yadav 1996). Wankhedkar \& Bhavsar (2015) found that total protein content significantly decreased in foot and hepatopancreas in land snail C. moussonianus when treated with Cartap hydrochloride and Imidacloprid at lowest concentration i.e. $\mathrm{LC}_{50} 0.41 \mathrm{ppm}$ and $\mathrm{LC}_{50} 0.54 \mathrm{ppm}$ respectively. Veeraiah et al. (2018) observed a decrease in protein content in all tissues exposed to lethal and sub-lethal concentrations of cyhalothrin $2.5 \%$ EC, in the fish Ctenopharyngdon idellus for 24 and $96 \mathrm{~h}$.

Proteins are important organic constituents of the animal cells. Understanding the protein components of the cell becomes necessary in the light of the radical changes taking place in protein profiles during pesticide intoxication (Anitha \& Rathnamma 2016). The decreased trend of the protein content as observed in the present study in most of the fish tissues may be due to metabolic utilization of the ketoacids through gluconeogenesis pathway for the synthesis of glucose or due to the directing of free amino acids for the synthesis of necessary proteins, or for the maintenance of osmotic and ionic regulation (Schmidt Neilson 1975).

\section{Nucleic Acids (DNA \& RNA)}

The changes in DNA content observed in the various tissues of Cirrhinus mrigala after the Cartap hydrochloride exposure along with the control was graphically represented in Fig. 5 and Fig. 6.

In control fish, DNA content present in different organs was in the order of:

\section{Muscle $>$ Gill $>$ Brain $>$ Liver $>$ Kidney.}

Under exposure to sub-lethal and lethal concentrations of Cartap hydrochloride, for $24 \mathrm{~h}$ the amount of DNA was found to decrease in all the tissue of Cirrhinus mrigala. The lyotropic gradation series in terms of per cent decrement at $24 \mathrm{~h}$ and $96 \mathrm{~h}$ exposure was:

Sub-lethal -24 h: Gill $>$ Liver $>$ Muscle $>$ Brain $>$ Kidney

Lethal-24 h-Gill $>$ Liver $>$ Muscle $>$ Brain $>$ Kidney

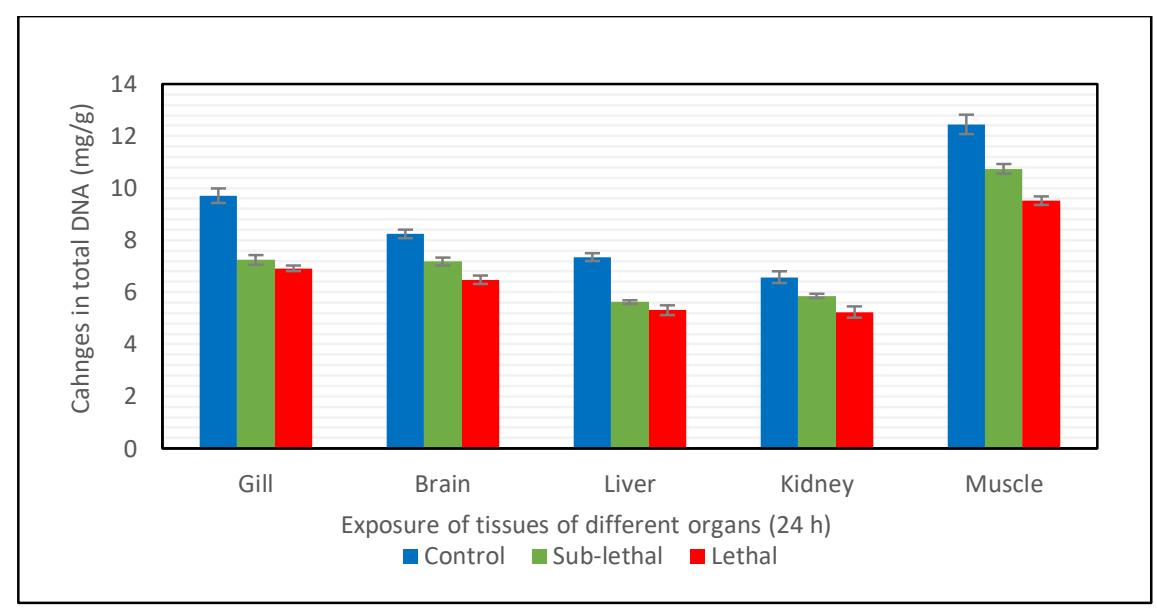

Fig. 5: Changes in the amount of deoxyribonucleic acid (DNA) (mg/g wet weight of the tissue) in different tissues of the fish, Cirrhinus mrigala on exposure to sub-lethal and lethal concentration of Cartap hydrochloride (50\% SP) for $24 \mathrm{~h}$. 


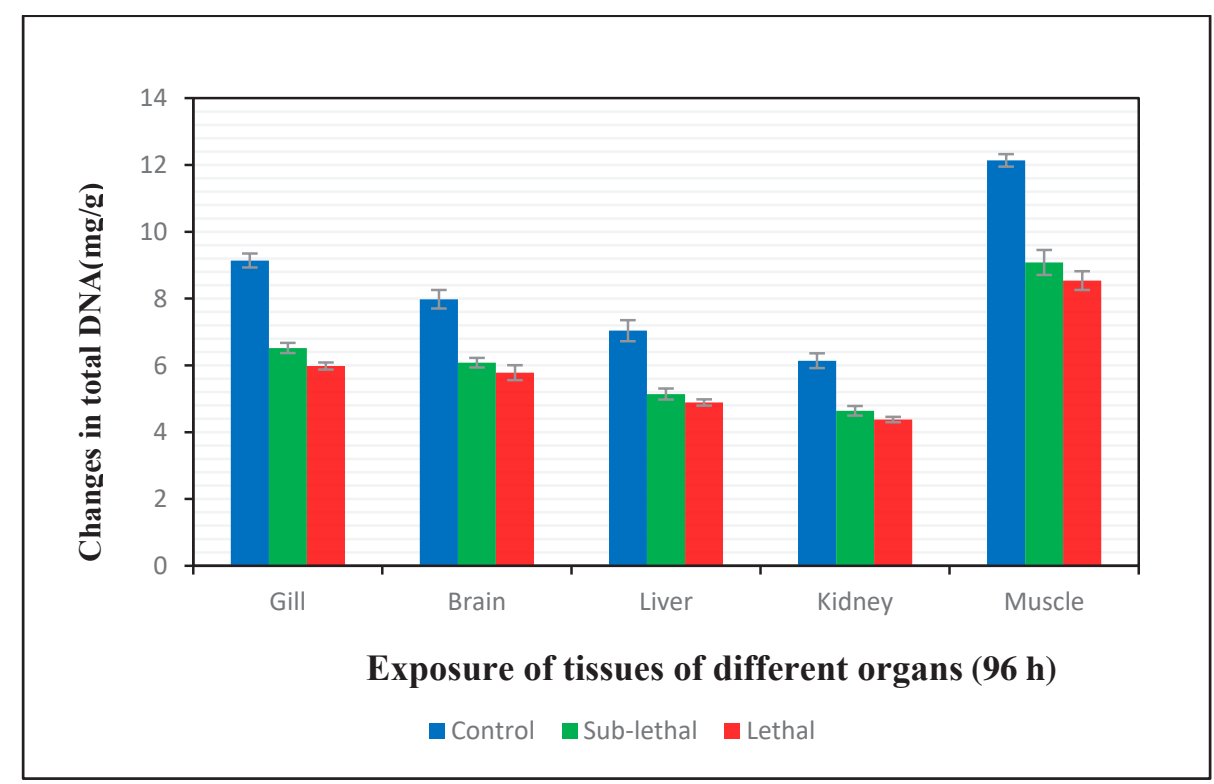

Fig. 6: Changes in the amount of deoxyribonucleic acid (DNA) (mg/g wet wt of the tissue) in different tissues of the fish Cirrhinus mrigala on exposure to sub-lethal and lethal concentration of Cartap hydrochloride (50\% SP) for $96 \mathrm{~h}$.

Sub-lethal-96 h: Gill $>$ Liver $>$ Muscle $>$ Kidney $>$ Brain

Lethal-96 h: Gill > Liver $>$ Muscle $>$ Kidney $>$ Brain

In the present study under Cartap hydrochloride exposure for $24 \mathrm{~h}$, maximum percentage of depletion in amount of DNA was noticed in Gill (sub-lethal 25.44, lethal 28.74). Minimum percentage of depletion was exhibited in the Kidney (sub-lethal 10.95, lethal 20.37). Under exposure to sub-lethal and lethal concentrations of Cartap hydrochloride for $96 \mathrm{~h}$, maximum percentage of depletion was seen in Gill (sub-lethal 28.67, lethal 34.58) and minimum percentage of depletion was noticed in the brain (sub-lethal 23.81, lethal 27.57).

The changes in RNA content observed in the various tissues of Cirrhinus mrigala after Cartap hydrochloride exposure along with the control was graphically represented in Fig. 7 and Fig. 8.

The RNA content in different tissues in control fish Cirrhinus mrigala was in the order of:

Muscle $>$ Brain $>$ Gill $>$ Liver $>$ Kidney.

Under exposure to lethal and sub-lethal concentrations of Cartap hydrochloride, for 24 and $96 \mathrm{~h}$, the amount of RNA was found to decrease in all the tissues. The lyotropic gradation series in terms of per cent decrement at $24 \mathrm{~h}$ and $96 \mathrm{~h}$ exposure was:

Sub-lethal -24h: Muscle $>$ Gill $>$ Kidney $>$ Brain $>$ Liver

Lethal-24h: Muscle $>$ Gill $>$ Kidney $>$ Liver $>$ Brain

Sub-lethal -96h: Gill $>$ Muscle $>$ Kidney $>$ Liver $>$ Brain

Lethal-96h: Gil $1>$ Muscle $>$ Liver $>$ Kidney $>$ Brain

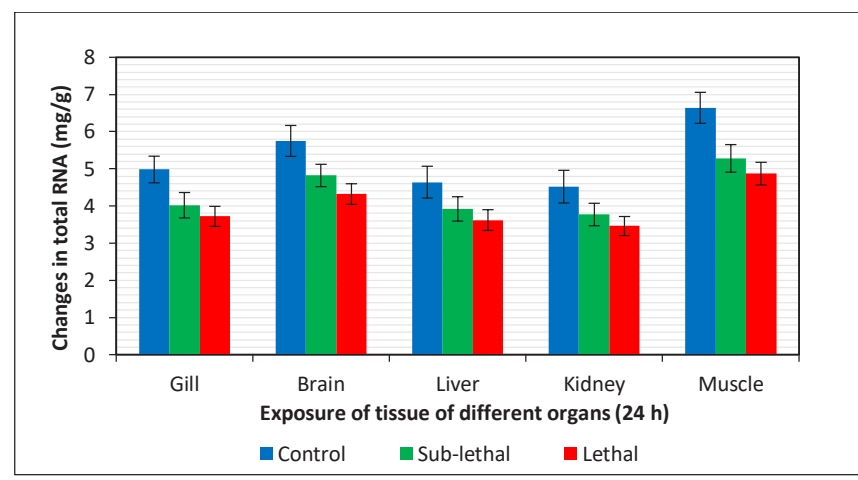

Fig. 7: Changes in the amount of ribonucleic acid (RNA) (mg/g wet wt of the tissue) in different tissues of the fish, Cirrhinus mrigala on exposure to sub-lethal and lethal concentration of Cartap hydrochloride (50\% SP) for $24 \mathrm{~h}$. 


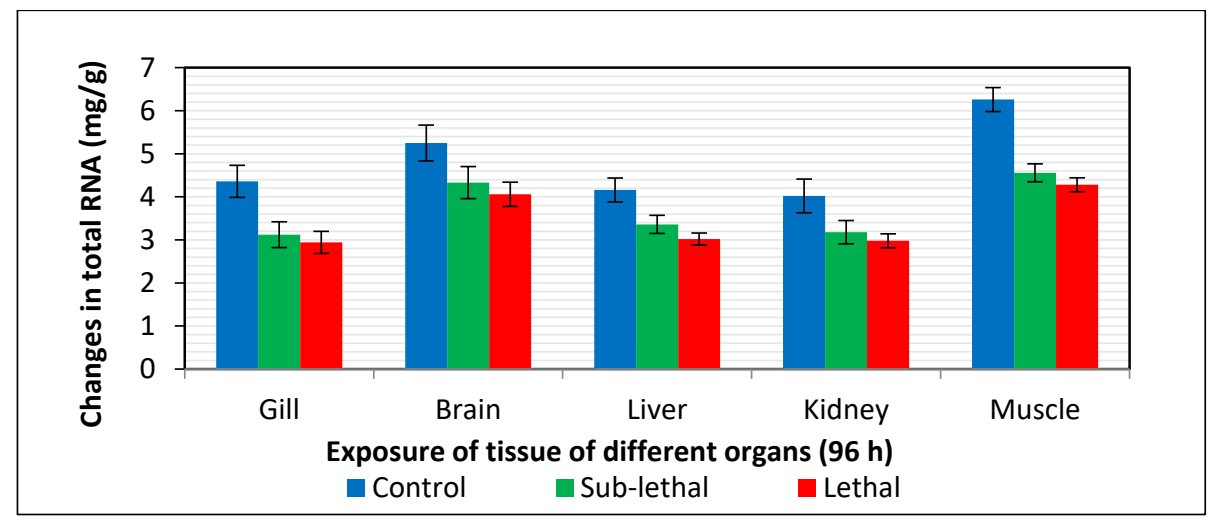

Fig. 8: Changes in the amount of ribonucleic acid (RNA) (mg/gm wet wt of the tissue) in different tissues of the fish, Cirrhinus mrigala on exposure to sub-lethal and lethal concentration of Cartap hydrochloride (50\% SP) for $96 \mathrm{~h}$.

After $24 \mathrm{~h}$ of exposure maximum percentage of decrease in the amount of RNA was found in muscle (sub-lethal 20.48, lethal 26.65). Minimum per cent of the decrease in RNA was found in the liver (15.51) in sub-lethal concentration and brain (19.65) in lethal concentration. After 96h of exposure maximum percentage of decrease in the amount of RNA was found in Gill (sub-lethal 28.44, lethal 32.56). Minimum percentage of decrease in RNA was found in brain(sub-lethal 17.52, lethal 22.66).

The results indicated that the DNA and RNA content in all the tissues of test fish were decreased compared to controls and the decreasing trend was more pronounced in lethal concentrations than in sub-lethal concentrations. In maintaining the physiological configuration of the fish Nucleic acids play a vital role. As Nucleic acid and protein play the main role in regulating different activities of cells they are regarded as important biomarkers of the metabolic potential of cells (Veeriah et al 2013a).

The decrease in nucleic acid content in the present study was in accordance with Vivek (2015) in fingerlings of Labeo rohita exposed to sub-lethal concentrations of Cartap hydrochloride for 24, 48, 72 and $96 \mathrm{~h}$. Similar results were also found by Dasu (2014) in fingerlings of Labeo rohita were exposed to Thiocarb (Larvin 75\% WP) a thiocarbamate pesticide. Anitha \& Rathnamma (2016) noticed decreased DNA and RNA levels in all the tissues like liver, kidney, brain, gill and muscle of Labeo rohita exposed to lethal and sub-lethal concentrations of Pyraclostrobin 20\%WG (carbamate) for $24 \mathrm{~h}$ and sub-lethal concentrations for 5 and 10 days.

Tilak et al. (2009) noticed a decreased level of DNA and RNA content in Alachlor treated freshwater fish, Channa punctatus (Bloch). The decrease of RNA may be due to inhibiting the function of RNA polymerase or due to interference in the incorporation of precursor in the nucleic acid synthesis. The alterations in DNA levels may be due to disturbances in DNA synthesis and its turnover rate besides degenerative changes caused by pesticides.

From the present study, it can be concluded that exposure of Cirrhinus mrigala to Cartap hydrochloride caused a decline in the glycogen, total protein and Nucleic acids (DNA, RNA) content which is more pronounced in lethal exposure than in sub-lethal exposure. The alterations caused during pesticide exposure may be due to the decreased catabolism of the biomolecules to meet the energy demand of test organism under stress or their reduced synthesis due to impaired tissue function. Therefore, the results of this study suggest a serious concern towards the potential danger of Cartap hydrochloride for the aquatic environment and organisms suggesting judicious and careful use of this pesticide in the agricultural area.

\section{ACKNOWLEDGEMENTS}

The authors are thankful to the UGC SAP-DRS-III for extending the infrastructure facilities to carry out the present work in the Laboratories of the Deptt. of Zoology \& Aquaculture and thank the Head, Department of Zoology and Aquaculture for permitting to do the work.

\section{REFERENCES}

Anitha, A. and Rathnamma, V.V. 2016. Toxicity Evaluation and Protein Levels of Fish Labeo rohita Exposed to Pyraclostrobin $20 \% \mathrm{Wg}$ (Carbamate). International Journal of Advanced Research, 4(3): 967-974.

APHA 1998. Standard Method for the Examination of Water and Wastewater, A.D. Eaton, L.S. Clesceri and A.E. Greenberg (Eds.), $20^{\text {th }}$ edition. American Public Health Association, AWWA and WEF, Washington D.C.

Bantu, N. and Rathnamma Vakita 2013. Effect of dimethoate on mortality and biochemical changes of freshwater fish Labeo rohita (Hamilton). Journal of Biology and Today's World, 2(10): 456-470. 
Borah, S. and Yadav, R.N.S. 1996. Effect of Rogor (30\% w/w dimethoate) on the activity of lactate dehydrogenase, acid and alkaline phosphatase in muscle and gill of a freshwater fish, Heteropneustes fossilis. Journal of Environmental Biology, 17(4): 279-283.

Cappon, I.D. and Nicholls, D.M. 1975. Factors involved in increased protein synthesis in liver Microsomes after administration of DDT. Pestic. Biochem. Physiol., 5: 109-118.

Chandravathy, V.M. and Reddy, S.L.N. 1996. Lead nitrate exposure changes in carbohydrate metabolism of freshwater fish. Journal of Environmental Biology, 17: 75-79.

Chaudhry, A.S. and Jabeen, F. 2011. Assessing metal, protein, and DNA profiles in Labeo rohita from the Indus River in Mianwali, Pakistan. Environ. Monit. Assess., 174(1-4): 665-679.

Dasu, P.M. 2014. Thiocarb $75 \%$ wp a carbamate insecticide induced toxicity biochemical and histopathological changes in the freshwater Indian major carp Labeo rohita Hamilton, Ph.D. Thesis, Acharya Nagarjuna University, Nagarjuna Nagar, Guntur, A.P, India

Dezwaan, A. and Zandee, D.I. 1973. Body distribution and seasonal changes in glycogen content of the common sea mussel, Mytilus edulis. Comp. Biochem. Physiol., 43: 53-55.

Dhanalakshmi, B. 2013. Acute and chronic toxicity of chromium on biochemical composition of the freshwater major carp Cirrhinus mrigala (Hamilton). Asian J. Sci. Technol., 4: 021-026.

Finney, D.J. 1971. Probit Analysis, $3^{\text {rd }}$ edition. Cambridge University Press.

Golterman, H. and Claimo, R.S. 1969. Methods for Chemical Analysis of Freshwater. Blackwell Sci. Pub., 166 pp.

Jabeen, F., Chaudhry, A.S., Manzoor, S. and Shaheen, T. 2016. Carbamates and neonicotenoids in fish, water and sediments from the Indus River for potential health risks. Environ. Monit. Assess., 187(2): 29.

Kafilzadeh, F., Shiva, A.H., Malekpour, R. and Azad, H.N. 2012. Determination of organochlorine pesticide residues in water, sediments and fish from Lake Parishan, Iran. World J. Fish. Mar. Sci., 4(2): 150-154.

Kemp, A. and and Van Heijningen, A.J.K. 1954. A colorimetric method for the determination of glycogen in tissues. Bio. Chem. J., 56: 646-648.

Kumar, A., Singh, S. and Sharma, H.N. 2017. Changes in total protein in Liver and Kidney of freshwater fish, Channa punctatus (Bloch.) after intoxication of Carbaryl. Journal of Advanced Laboratory Research in Biology, 8(2): 41-43.

Kumari, A., Srivastava, A. and Jha, M.M. 2014. Carbaryl Induced alteration in histology and certain biochemical parameter in liver of Clarias batrachus. Global Journal of Bioscience and Biotechnology, 3(3): 259-263.

Lowry, O.H., Rosebrough, N.J., Farr, A.L. and Randall, R.J.1951. Protein measurement with the Folin Phenol Reagent. J. boil. Chem., 193: 265-275

Mayers, P. A. 1977. In: Review of Physiological Chemistry, $16^{\text {th }}$ edition. Eds: Harper H A. Rodwell U V and Mayers P.A. Large Medical Publications, California.

Muddassir, A.T. 2015. Comparative study of biochemical alterations induced by carbofuran and malathion on Channa punctatus (Bloch.). International Research Journal of Biological Sciences, 4(9): 61-65.

Muley, D.V., Kamble, G.B. and Gaikwad, P.T. 1996. Endosulfan toxicity in the freshwater fish Tilapia mossambica. Journal of Aquatic Biology, 11: 61-66.

Naik, B. R., Rao, G. N. and Neelima, P. 2016. Sub-lethal toxicity of cyperkill (a synthetic pyrethroid pesticide) on glycogen content in the tissues of Labeo rohita. Int. J. Curr. Res. Aca. Rev., 4(12): 127-134.

Pillai, S.K. and Sinha, H.C.1968. Statistical Methods for Biological Works. Ramprasad and Sons, Agra.

Prasada Rao, G. D. V., Veeraiah, K., Krishna, Ch., Rajeswari, A. and
Sindhoori, E. 2018. Cyhalothrin induced bio-chemical alterations in the grass carp Ctenopharyngodon idellus (Valenciennes). European Journal of Biomedical and Pharmaceutical Sciences, 5(9): 525-536.

Priya, B.P. and Maruthi, Y.A. 2013. Imidacloprid toxicity on biochemical constituents in liver tissue of fresh water teleost Channa punctatus. International Journal of Pharma and Bio Sciences, 4(4b): 50-54.

Rajamanickam, C. 1992. Effects of Heavy Metal Copper on the Biochemical Contents, Bioaccumulation and Histology of the Selected Organs in the Freshwater Fish, Mystus Vittatus (Bloch). Ph.D. Thesis, Annamalai University, India.

Rajamannar, K. and Manohar, L. 1998. Sublethal toxicity of certain pesticides on carbohydrates, proteins and amino acids in Labeo rohita. J. Ecobiol., 10(3): 185-191.

Rawat, D.K., Bais, V.S. and Agrawal, N.C. 2002. A correlative study on liver glycogen and endosulfan toxicity in Heterpneustes fossilis. J. Environ. Biol., 23: 205-207.

Roberts, M. and Boyce, C.B.C. 1972. In Methods in Microbiology. 7-A Edition. (eds: J.R. Norris and D.W. Ribbows). Academic Press, New York, pp 479.

Sastry, K.V. and Abad A Siddiqui. 1982. Chronic toxic effects of the carbamate pesticide Sevin on carbohydrate metabolism in a freshwater snakehead fish, Channa punctatus. Toxicology Letters, 14(1-2): 123130.

Schmidt Nielson, B. 1975. Osmoregulation: Effect of salinity and heavy metal. Fed. Proc., 33: 2137-2146.

Searchy, D.G. and MacLennis, A.J. 1970a. Determination of DNA by the Barton Diphenylanine technique. In: Experiments and Techniques in Parasitology. (eds: A.J. Mac Lnnis and M. Voge) W.H. Freeman and Co, San-Franscisco, 190-191 pp.

Searchy, D.G. and MacLennis, A.J. 1970b. Determination of RNA by Dische orcinol technique. In: Experiments and Techniques in Parasitology. (eds: A.J. Mac Lennis and M. Voge). W.H. Freeman and Co, San-Francisco, pp. 189-190.

Shivanagouda, N., Sanagoudra and Bhat, U.G. 2013. Carbaryl induced changes in the protein and cholesterol contents in the liver and muscle of marine benthic fish, Mugil cephalus. American Journal of Biochemistry, 3(2): 29-33.

Singh, A. and Singh, A. 2017. Studies on toxicity stress, behavioural alterations and biochemical changes induced by glyphosate herbicide on the freshwater fish, Channa punctatus (Bloch). Int. J. Food Agricul. Veter. Sci., 7(3): 39-48.

Singh, R.K. and Sharma B. 1998. Carbofuran induced biochemical changes in Clarias batrachus. J. Pestic. Sci., 53: 285-290.

Srivastava, P. and Singh, A. 2013. In vivo study of effects of dithiocarbamates fungicide (mancozeb) and its metabolite ethylene thiourea (ETU) on freshwater fish Clarius batrachus. Journal of Biology and Earth Sciences, 3(2): B228-B235.

Tataji, P.B. and Kumar, M.V. 2016. Biochemical changes induced by Butachlor and Machete 50\% EC to the freshwater fish Channa punctata (Bloch). International Journal of Science and Research, 5: 2048-2052.

Tilak, K.S., Raju, P.W. and Butchiram, M.S. 2009. Effects of alachlor on biochemical parameters of the freshwater fish, Channa punctatus (Bloch). J. Environ. Biol., 30(3): 421-426.

Veeraiah, K., Venkatrao, G., Vivek, Ch. and Hymaranjani, G. 2013a. Heavy metal, cadmium chloride induced biochemical changes in the Indian major Cirrhinus mrigala (Hamilton). Int. J. Bioassays, 2(07): 1028-1033.

Veeraiah, K., Vivek, Ch., Srinivas Rao, P. and Venkatrao, G. 2013b. Biochemical changes induced by Cypermethrin (10\% EC), a pyrethroid compound in sub-lethal and lethal concentrations to the freshwater fish 
Cirrhinus mrigala (Hamilton). J. Atoms and Molecules, 3(6): 625-634. Vivek, Ch. 2015. Impact of Cartap Hydrochloride (50\% SP) on Biochemical, Haematological and Enzymatic Activities of the Freshwater Fish, Labeo Rohita (Hamilton). Ph.D. Thesis submitted to Acharya Nagarjuna
University, Nagarjuna Nagar, Guntur, A.P, India.

Wankhedkar, P. T. and Bhavsar, S.S. 2015. Effect of Cartap hydrochloride and Imidacloprid on biochemical parameters of Cerastus moussonianus. Biolife, 3(1): 125-131. 